\title{
Mısırda Koçan ve Tane Ölçümlerinde Kullanılan Görüntü İşleme Yazılımlarından Elde Edilen Sonuçların Karşılaştırılması
}

\author{
Murat Cirit $^{1 *}$, Ferhat Kaya ${ }^{2}$, Niyazi Kılıç ${ }^{3}$, Fatih Kahrıman ${ }^{4}$ \\ 1*Çanakkale Onsekiz Mart Üniversitesi, Ziraat Fakültesi, Tarla Bitkileri Böl., Çanakkale, Türkiye, (ORCID: 0000-0003-0479-5181), murat_cirit_1905@hotmail.com \\ ${ }^{2}$ Çanakkale Onsekiz Mart Üniversitesi, Ziraat Fakültesi, Tarla Bitkileri Bölümü, Çanakkale, Türkiye, (ORCID: 0000-0003-1447-7291), ferhattkaya6@gmail.com \\ ${ }^{3}$ Çanakkale Onsekiz Mart Üniversitesi, Ziraat Fakültesi, Tarla Bitkileri Bölümü, Çanakkale, Türkiye, ORCID: 0000-0003-3054-3957), klc.niyazi00@gmail.com \\ ${ }^{4}$ Çanakkale Onsekiz Mart Üniversitesi, Ziraat Fakültesi, Tarla Bitkileri Bölümü, Çanakkale, Türkiye, (ORCID: 0000-0001-6944-0512), fkahriman@hotmail.com
}

(İlk Geliş Tarihi 11 Haziran 2021 ve Kabul Tarihi 17 Aralık 2021)

(DOI: 10.31590/ejosat.950996)

ATIF/REFERENCE: Cirit, M., Kaya, F., Kılıç, N. \& Kahrıman, F. (2022). Mısırda Koçan ve Tane Ölçümlerinde Kullanılan Görüntü İşleme Yazılımlarından Elde Edilen Sonuçların Karşılaştııılması. Avrupa Bilim ve Teknoloji Dergisi, (33), 20-25.

\begin{abstract}
Özet
Mısır ıslahı ve yetiştiriciliğine yönelik araştırmalarda koçan ve tane özelliklerinin belirlenmesine yönelik öçümlere ihtiyaç duyulmaktadır. Geleneksel ölçümler oldukça fazla zaman alan ve fazla işgücü gerektiren yöntemelere dayanmaktadır. Son yıllarda bilgisayar bilimlerinin tarımsal araştırmalarda kullanımı oldukça yaygınlaşmış ve koçan/tane özelliklerinin görüntü analizlerine dayalı olarak belirleyebilen çeşitli alternatifler yazılımlar geliş̧irilmiştir. Bu çalışmada açıkta ve kontrollü tozlama yöntemleri ile 20 farklı genotipten elde edilen koçan örnekleri kullanılarak iki farklı yazılımın karşılaştırılması amaçlanmıştır. Çalışmada görüntü işleme yazılımı olarak SmartGrain ve Fiji seçenekleri denenmiştir. Koçan uzunluğu $(\mathrm{cm})$, koçan çapı $(\mathrm{cm})$, koçanda tane sayısı (adet), tane çevresi $(\mathrm{mm})$, tane boyu $(\mathrm{mm})$ ile ilgili görüntü işleme yazılımları ile alınan sonuçlar kıyaslanmıştır. Araştırma bulgularına göre mısırda koçan ve tane gelişimini önemli şekilde etkileyen tozlama yöntemlerinin ölçülen özelliklerden bazıları üzerine önemli etkilere sahip olduğu görülmüsştür. Kullanılan genotip gruplarına göre tozlama yöntemlerinin etkileri değişkenlik göstermiştir. İncelenen özelliklerden koçanda tane sayısının her iki yazılım ile de mükemmel bir şekilde tespit edilebileceği ( $(\mathrm{r}=1)$, buna karşın tane uzunluğu ve tane çevresi gibi ölçümlerde yazılımlardan elde edilen sonuçlar arasındaki benzerliğin zayıf olduğu dikkat çekmiştir.
\end{abstract}

Anahtar Kelimeler: Görüntü analizi, Tohum morfolojisi, Koçan morfolojisi, Zea mays.

\section{Comparison the Results Obtained from Image Processing Software Used for Ear and Kernel Measurements of Maize}

\begin{abstract}
In studies on maize breeding and cultivation, ear and kernel measurements are needed. Traditional measurements are based on methods that are very time consuming and labor intensive. In recent years, the use of computer science in agricultural research has become widespread and various alternative software has been developed that can determine the ear/kernel characteristics based on image analysis. In this study, it is aimed to compare two different softwares by using ear samples obtained from 20 different genotypes by open and controlled pollination methods. In the study, SmartGrain and Fiji options were tried as image processing software. The results obtained with the image processing software were compared regarding the ear length $(\mathrm{cm})$, the ear diameter $(\mathrm{cm})$, the number of kernels per ear (number), the kernel circumference $(\mathrm{mm})$, the kernel lenght $(\mathrm{mm})$. According to the findings of the research, it has been observed that pollination methods that significantly affect the ear and kernel development in maize have significant effects on some of the measured traits. The effects of pollination methods varied according to the genotype used. It was noted that the number of kernels per cob could be determined perfectly by both software $(\mathrm{r}=1)$, but the similarity between the results obtained from the software was weak in measurements such as grain lenght and grain circumference.
\end{abstract}

Keywords: Image analysis, Kernel morphology, Ear morphology, Zea mays.

* Sorumlu Yazar: murat_cirit_1905@hotmail.com 


\section{Giriş}

Mısır bitkisinin anavatanı Güney Amerika'dır ve dünyanın diğer bölgelerine Amerika kıtasının keşfinden sonra taşınmıştır. Mısır bitkisi farklı gıda maddelerinin üretiminde kullanılmaktadır (Yusuf ve ark, 2014). Tarımsal üretimde misır, geleneksel gida ve hayvan yemi olarak rol oynayan endüstriyel bir hammaddedir. Farklı alanlarda kullanılan mısırda ihtiyaç duyulan ürün miktarının karşılanması için yüksek verimli çeşitlerin geliştirilmesine ihtiyaç duyulmaktadır. Bu nedenle, mısırda temel sslah amaçlarından birisi verimin artırılmasıdır. Mısırda tane verimi koçanların büyüklügüne, şekline, sayısına ve taşıdıkları tanelere bağlıdır. Verim artışı için ise verime etki eden özelliklerle ilgili ölçüm ve gözlemlerin yapılması gerekmektedir. Koçan ve tane özellikleri mısırda verimle ilişkili olduğu kabul gören özelliklerdir. Bu özellikler bitki başına koçan sayısı, koçan başına tane, tane uzunluğu, tane genişliğidir (Liang ve ark, 2016). Tane boyutuyla ile ilgili özellikler de doğrudan verimi etkilemektedir (Liu ve ark, 2019). Bu özellikler bilimsel literatürde en fazla çalışılan özellik grupları içerisindedir. Bunun temel nedeni hem koçan hem de tane morfolojisindeki değişimlerin tane verimi üzerine etkili olmasıdır.

Klasik metotlarla yapılan koçan ve tane ölçümleri yüksek iş gücü gerektiren ve uzun süre alan ölçümlerdir. Çoğu zaman fazla materyal ile çalışması gereken ıslah programlarının süresi ve etkinliğinin artırılması istendiğinden klasik ölçüm yöntemleri bu programları olumsuz etkilemektedir. Diğer taraftan klasik ölçüm teknikleri zaman alıcı ve en yüksek hata oranına sahiptir. (AngWu ve ark. 2018). Bu nedenle daha pratik olan yöntemler üzerine yüksek bir çaba harcanmaktadır. Geliştirilen ölçüm yöntemleri özel bilgisayar programları yardımıyla koçan ve tane görüntülerinin işlenmesine yönelik araçlar geliştirilmiştir. $\mathrm{Bu}$ araçlar genel olarak kendi başına çalışan yazılımlar olabildiği gibi, açık kaynak kodlu ve ücretsiz platformlarda çalışabilir makrolar şeklinde hazırlanmıştır. Farklı bitki türlerinde tane morfolojilerinin görüntü verileri üzerinden tespit edebilen SmartGrain yazılımı bu seçeneklerden birisidir. Smart Grain yazılımı ile tane ölçümlerinin yapılması etkin ve hızlı bir çözüm sunmaktadır (Tanabata ve ark, 2012). SmartGrain yazılımı alan, çevre, uzunluk, genişlik gibi tohum parametrelerini belirlememizi sağlar ancak tohum rengi hakkında bir bilgi vermemektedir (Tanabata ve ark., 2012). Tohum analizlerini görüntü verilerine dayalı olarak yapabilen diğer bir alternatif yazılım GrainScan yazılımıdır. Bu yazılım tohum boyutu ve rengi hakkında sonuç verebilmektedir (Whan ve ark., 2014). Bunlara ilaveten tohum morfolojilerinin analizlerini gerçekleştirebilen SeedExtractor de Matlab programlama dili ile geliştirilmiş diğer bir yazılımdır (Zhu ve ark., 2020). Açık kaynak kodlu görüntü işlemeye dayalı araçlar içerisinde ImageJ plarfoptmunda çalışan yazılımlar da mevcuttur. Uluslararası Misır ve buğday geliştirme merkezindeki (CIMMYT) araştırmacılar daha fazla sayıda mısır materyalinin koçan ve tane özellikleri hakkında daha doğru verileri toplamak için ImageJ platformunda çalışan bir program dosyası geliştirmiştir. $\mathrm{Bu}$ platform üzerine kurgulanmış Fiji olarak isimlendirilen versiyonu da mevcuttur. ImageJ/Fiji platformunda görüntü işleme araçlarının kullanılabilmesi için, ImageJ/Fiji programının analiz yapılacak bilgisayarda kurulu olması gerekir. Analiz dosyası bu yazılımın makro klasörüne konulduktan sonra ImageJ/Fiji platformu koçan/tane görüntü analizlerinin yapılması için hazır hale gelmektedir. Görüntü işlemeye dayalı analiz sonuçları verebilen bu yazılımlar farklı bitki türlerinde de kullanıma uygundur ve bilimsel çalışmalarda farklı amaçlarla kullanılmışlardır.

Görüntü işleme teknikleri ve geliştirilen programlar yüksek verimli bilgi işlem ve dağıtılmış veri depolama özelliğine sahip bir alt yapıdır. $\mathrm{Bu}$ sistemlerden elde edilen veriler uzun süreli kayit altında tutulabilmekte ve farklı amaçlar ile de kullanılabilmektedir. Görüntü işleme yoluyla tane ve koçan özelliklerinin belirlenmesine izin veren birkaç yöntem vardır. 2009 yılında Pioneer (Hi-Bred International, inc., lowa) tarafından patentlenen bir yöntemde görüntü işleme tekniklerini kullanarak tane sayısı, tane boyutu hakkında bilgi sahibi olunmasını sağlamaktadır. Filtreleme, sınır belirleme, kenar bulma, renk seçimi ve spektral filtrelemeyi içeren algoritmaları kullanarak tane sayısını tane boyutu dağılımı hakkında bilgi edinmemizi sağlamaktadır. Kontrollü aydınlatma koşulları altında misır tanesinin özelliklerini puanlayan yöntem (Miller ve ark., 2017) tarafından geliştirilmiştir. Tane boyutu özelliklerine ilişkin farklı tane boyutlarına sahip dört kendilenmiş mısır hattı üzerinde bir eşleme popülasyonu geliştirilmiştir (Jiafa Chen ve ark., 2016). Mısırda tane sayısı üzerine yapılan bir çalışmada önce elle referans ölçümleri alınıp daha sonra dijital kamera ile $50 \mathrm{~cm}$ yükseklikten ve $45 \mathrm{~cm}$ bir alandan görüntüler alınmıştır. ImageJ tabanlı görüntü işleme yazılımı ile tane sayısı karşılaştırılmıştır. Karşılaştırma sonucunda ulaşılan verilen \%95 güven aralığında 100 ila 700 tane arasında değişmektedir. (Severini ve ark., 2011). Zhu ve ark., (2020) tarafından yürütülen çalışmada SeedExtractor yazılımını kullanarak alan, çevre, uzunluk, genişlik, dairesellik ve ağırlık merkezi sonuçlarını bulmuşlardır. SeedExtractor yazılımının SmartGrain yazılımından 30 kat, GrainScan yazılımından ise 6 kat daha hızlı olduğu görülmüştür. Görüntü işleme yazılımlarının büyük çoğunluğu tane tutumu sağlayan materyallere yönelik test edilmiştir. Tozlama yöntemleri koçan ve tane tutumuna yönelik büyük oranda rol oynamaktadır. Mevcut yazılımların farklı yöntemlerle çoğaltılmış koçan örnekleri üzerinde geçerli sonuç verilip verilmediği hala bilinmemektedir.

Bu çalışmanın amaçları; i) Farklı mısır genotiplerinde koçan ve tane özelliklerindeki değişime farklı tozlama yöntemlerinin etkisinin araştırılması, ii) Geleneksel ölçüm yöntemleri ile görüntü işleme yazılımlarından elde edilen sonuçların karşılaştırılmasıdır.

\section{Materyal ve Metot}

\subsection{Deneme Materyali ve Tarla Denemesi}

$\mathrm{Bu}$ çalışmada materyal olarak 20 adet mısır genotipi kullanılmıştır (Tablo 1). Bu genotipler tane rengi endosperm yapısı ve genel karakteristikleri bakımından farklılık gösteren materyallerdir. Ayrıca mısır çalışmalarına konu olan 5 farklı materyal grubuna örnek olarak seçilmişlerdir. Tarla denemesi Çanakkale Onsekiz Mart Üniversitesi, Ziraat Fakültesi, Dardanos Araştırma ve Uygulama Birimin'nde yürütülmüştür. Deneme alanı killi-tınlı toprak yapısına sahip olup, mısır yetiştiriciliği için uygun niteliktedir. İklim özellikleri bakımından Çanakkale ili geçiş iklimi özelliği göstermektedir. Deneme sezonunda da iklim özellikleri bakımından uzun yılllar ortalamalarına benzer bir yıl yaşanmıştır. Tarla denemesinde her genotip tek sıralı iki metrelik parsellere ekilmiştir. 2020 yılında mayıs ayının 2. haftasında gerçekleştirilmiştir. Sıra arası mesafe $70 \mathrm{~cm}$, sıra üzeri mesafe ise $20 \mathrm{~cm}$ olacak şekilde ekim yapılmış ve dekara 7140 bitki hedeflenerek bu işlem gerçekleştirilmiştir. Deneme iki tekerrürlü olarak kurulmuş ve tesadüf blokları deneme desenine göre yürütülmüştür. 
Tablo 1. Çalışmada Kullanılan Genotipler (Table 1. The genotypes used in this study)

\begin{tabular}{l|c|c}
\hline Materyal Türü & Kodu & Temin Edildiği Yer \\
\hline Yerel Popülasyonlar & KP1, KP2, KP3, KP4, KP5, KP6, KP7 & ÇOMÜ \\
\hline Deneysel Hibrit & D1, D2, D3 & ÇOMÜ \\
\hline Kendilenmiş Hat & HAT1, HAT2, HAT3, HAT4, HAT5, HAT6, HAT7, HAT8, HAT9 & ÇOMÜ \\
\hline Ticari Hibrit & TH1 & MAY Tohum \\
\hline
\end{tabular}

Genotipler arasında polen bulaşmasının engellenmesi ve materyallerin kendi karakterlerini koruması açısından kontrollü tozlama yöntemi uygulanmıştır. Çalışmada Kahrıman ve ark. (2015) tarafindan önerilen toplu tozlama yöntemine göre tozlamalar gerçekleştirilmiştir. Bu amaçla çiçeklenme zamanında her bir sıra ayrı ayrı kontrol edilerek ve koçan ucu görünen bitkilerin koçanı özel bir kâğıt yardımı ile koruma altına alınmıştır. Her sırada koruma altına alınan bitkilerden 3-5 adedine tepe püskülü kâğıdı takılmıştır. Bu işlem tozlamadan bir gün öncesinde gerçekleştirilmiştir. Tozlama işlemi ertesi gün sabah 8:00 ile 10:00 saatleri arasında yapılmıştır.

Tarla denemesinde bitkilerin sağlıklı olarak gelişebilmesi için gerekli olan bakım ve yetiştiricilik işlemleri yerine getirilmiştir. Deneme alanı damla sulama sistemi ile 7-10 gün sıklıkla sulanarak ve bitkilerin gelişim durumu ve topraktaki nem durumuna göre ilave sulama yapılmıştır. Gübreleme işlemi sulama ile birlikte dekara $18 \mathrm{~kg}$ saf azot hesabiyla her sulamayla birlikte eşit miktarda olacak şekilde bölünmek suretiyle uygulanmıştır.

\subsection{Koçan Analizleri}

Tarla denemesinde bitkilerin hasat zamanı dış görünüşlerine göre ve koçan nem içeriklerine göre belirlenmiştir. Yaprakları kuruyan bitkilerde pin tipi nem ölçer (MT808 Moisture Meter, Electrophysics, Canada) kullanılarak nem içeriği Reid ve ark (2010) tarafından önerilen yönteme göre tespit edilmiştir ve nem içeriği \%20-30 arasında hasat gerçekleştirilmiştir. Her genotip başına 6 adet açıkta tozlanan 6 adet kontrollü tozlanan koçan hasat edilmiş ve bu örnekler üzerinde çalışma yürütülmüştür. Hasat sonrasında yapılan referans ölçümleri aşağıdaki yöntemlere göre yapılmıştır.

Koçan Uzunluğu (cm): Örneklenen koçanlar kavuzlarından ayrıldıktan sonra cetvel yardımıyla ölçümler yapılmıştır.

Koçan Çapı (mm): Koçanın orta kısmında dijital kumpas kullanılarak ölçümler elde edilmiştir.

Koçan görüntülerinin alınmasında ve görüntü işleme analizleri sırasında iki farklı görüntü işleme yazılımından yararlanılmıştır. Yararlanılan programlar ImageJ/Fiji ve Uluslararası Buğday ve Mısır Araştırma Merkezi (CIMMYT) tarafından geliştirilen EarAnalyzer programıdır. Koçan ölçümleri alınan örneklerden Makanza ve ark. (2018) tarafından önerilen yönteme göre ölçümler alınmıştır. Koçan örneklerinden $40 \mathrm{~cm}$ uzakta konumlandırılan fotoğraf makinesi (16 megapixel çözünürlüklü) yardımıyla dijital görüntü alınmıştır. Arka fon olarak 2 farklı fon kullanılmıştır. Siyah ve kırmızı renkli tohumlar için beyaz fon kullanılmıştır. Alınan görüntüler bu programın geliştiricileri tarafından önerilen işlem basamaklarına göre gerçekleştirilmiş sonuçlar kaydedilmiştir.

\subsection{Tane Analizleri}

Koçan görüntüleme analizlerinin ardından koçanlar tanelenmiş aşağıda belirtilen yöntemlere göre ölçümler yapılmış ve görüntü işleme sonucunda elde edilen verilerin eşleştirilebilmesi için tohum tepsilerinde sıralı olarak muhafaza edilmiş ve ölçümlere genotip-uygulama kodları verilerek tane ölçümleri kayıt altına alınmıştır.

Koçanda Tane Sayısı (adet): Koçan ölçümlerinin tamamlanmasının ardından her koçan örneği ayrı ayrı tanelenerek sayılmış ve tek koçanda tane sayısı belirlendikten sonra bu örnekler birbiriyle karışmayacak şekilde tane ve sömek örnekleri olarak muhafaza edilmiştir.

Referans ölçümleri alınan taneler tohum tepsilerindeki sıraları bozulmayacak şekilde görüntü alma işleminde kullanılmıştır. Bu kapsamda her koçana ait tohum görüntüleri masaüstü tarayıcı ve standart fotoğraf makinesi kullanılarak en az 300 dpi çözünürlükte JPEG formatında kaydedilmiştir. Alınan görüntüler ayrı ayrı Fiji (ImageJ) ve SmartGrain yazılımlarına aktarılmış tohum morfolojisi ile ilgili sonuçlar kayıt altına alınmıştır. Fiji programına dijital görüntülerin alınması ve işlenmesi Makanza ve ark. (2018), SmartGrain programındaki analizler ise Tanabata ve ark (2012) tarafından önerilen şekilde gerçekleştirilmiş ve sonuçlar kayıt altına alınmıştır.

\section{4. İstatistik Analizler}

Çalışmadan elde edilen veriler $\mathrm{R}$ paket programında analiz edilmiştir ( $\mathrm{R}$ Core Team, 2019). Genotip ve tozlama uygulamalarının etkisini irdelemek amacıyla faktöriyel düzende varyans analizi yapılmıştır. Farklı bulunan varyans kaynaklarına ait ortalamalar t testi ile karşılaştırılmıştır. Bu kapsamda genotip ortalamaları genel ortalama ile karşılaştırılarak grafiksel olarak gösterilmiştir. Açıkta tozlama ve kendileme uygulamaları ise genotip düzeyinde ayrı ayrı kıyaslanmıştır. Referans ölçümler ve görüntü işleme yazılımlarından elde edilen sonuçlar arasındaki benzerlikler Pearson korelasyonu ile irdelenmiştir. Korelasyon analizleri grafiksel olarak gösterilmiştir.

\section{Araştırma Sonuçları ve Tartışma}

\subsection{Koçan Ölçümü Sonuçları}

Yapılan varyans analizi sonucunda koçan boyu değerlerinin referans analiz ölçümlerinde ve görüntü işleme analizlerinde, genotip, tozlama yöntemi ve G x T interaksiyonundan etkilendiği görülmektedir (Tablo 2). Çalışmanın sonucunda araştırmada kullanılmış olan mısır çeşitlerinin Koçan çap1 değerlerinin referans ölçümlerinde ve görüntü işleme yöntemlerindeki değerlerinin tozlama yönteminden, genotip ve $\mathrm{G} \quad \mathrm{x} \quad \mathrm{T}$ interaksiyonundan etkilenmişlerdir (Tablo 2). 
Tablo 2. Koçan Özelliklerine ait Varyans Analizi Sonuçları (Table 2. The Resutls of Variance Analysis for Ear Traits)

\begin{tabular}{l|c|c|c|c|c}
\hline Varyans Kaynağı & SD & $\begin{array}{c}\text { Koçan Boyu } \\
\text { (Referans) }\end{array}$ & $\begin{array}{c}\text { Koçan Boyu } \\
\text { (Fiji) }\end{array}$ & $\begin{array}{c}\text { Koçan Çapı } \\
\text { (Referans) }\end{array}$ & $\begin{array}{c}\text { Koçan Çapı } \\
\text { (Fiji) }\end{array}$ \\
\hline Tekerür & 2 & 0.41 & 3.08 & 0.05 & 0.13 \\
\hline Genotip $(G)$ & 19 & $69.9^{* *}$ & $84.3^{* *}$ & $1.67^{* *}$ & $2.79^{* *}$ \\
\hline Tozlama $(T)$ & 1 & $17.6^{* *}$ & $36.9^{* *}$ & 0.04 & 0.01 \\
\hline GxT & 19 & $8.15^{* *}$ & $12.4^{* *}$ & $0.36^{* *}$ & $0.53^{* *}$ \\
\hline Hata & 78 & 2.48 & 4.24 & 0.08 & 0.12 \\
\hline
\end{tabular}

$* \mathrm{P}<0.05 ; * * \mathrm{P}<0.01$

Yapılan korelasyon analizi sonuçlarına göre, cetvel ile ölçülen koçan boyu değerleri ve görüntü analizleri ile elde edilen değerler arasında pozitif yönde ve istatistiki olarak önemli bir korelasyon olduğu $(\mathrm{r}=0.95 ; \mathrm{p}<0.05)$ belirlenmiştir (Şekil 1). Farklı tozlama uygulamalarında bu ilişkinin önemli bir değişime uğramadığı dikkat çekmektedir. Yapılan korelasyon analizi sonuçlarına göre, referans ölçümlerinde koçan çapı değerleri ve Fiji görüntü analizleri ile elde edilen değerler arasında pozitif yönde ve istatistiki olarak önemli bir korelasyon olduğu $(\mathrm{r}=0.92)$ belirlenmiştir (Şekil 1). Farklı tozlama uygulamalarında bu ilişkinin önemli bir değişime uğramadığı dikkat çekmektedir.
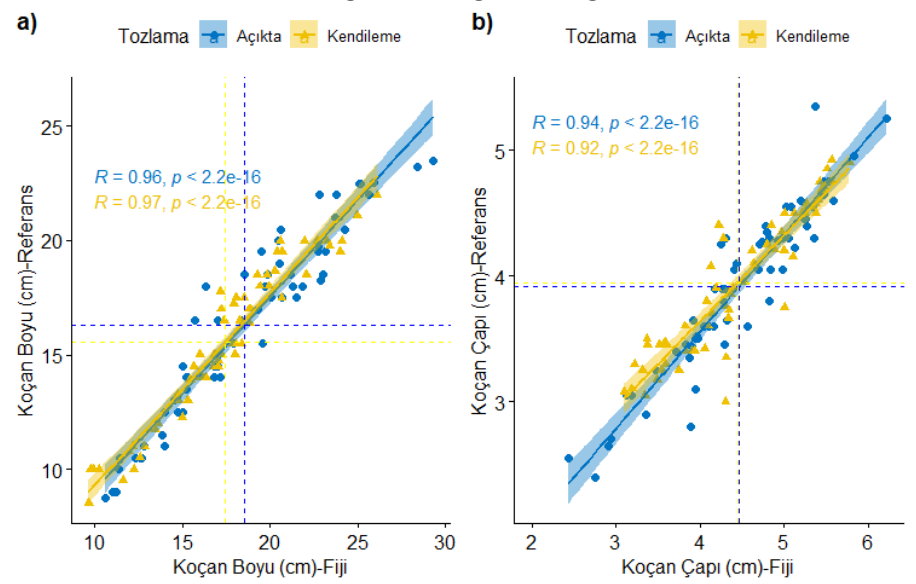

Şekil 1. Açıkta tozlama ve kendileme uygulamalarından referans ve görüntü işleme yöntemleri ile elde edilen koçan boyu (a) ve koçan çapı (b) ölçümleri arasındaki ilişkiler (Figure 1. Relationships between ear length (a) and ear diameter (b) measurements obtained by reference and image processing methods from open pollination and selfing applications)
Koçan boyu misırda verim ile ilişkilendirilen önemli özelliklerden birisidir (Li ve ark., 2020). Bu çalışmada alınan ölçümlere dayalı olarak koçan boyu değerlerinin bazı materyallerde tozlama yöntemi ve kullanılan genotipin etkileşiminden kaynaklanan nedenlerle farklı sonuçlar verebileceği anlaşılmaktadır. Buna karşın korelasyon testi sonuçlarının her iki tozlama yöntemi için de yüksek $(r=0.95)$ bulunmuş olması görüntü analizlerine dayalı koçan boyu ölçümlerinin çoğu materyal için güvenilir sonuç verdiğini göstermiştir. Miller ve ark. (2017) görüntü işlemeye dayalı koçan uzunluğu ölçümlerinin referans ölçüm ile arasında 0,99'luk bir korelasyon olduğunu belirlemiştir. Koçan uzunluğu ölçümlerinde bizim çalışmamızda tespit edilen korelasyon bu çalışmadan düşük bulunmuştur. $\mathrm{Bu}$ durumun temel nedeni kullanılan yazılımların algoritmaları ve görüntü işleme sürecinde uygulanan adımların farklı olmasından ileri gelmektedir. Ayrıca bizim çalışmamızda kullanılan materyallerin genetik özellikleri bakımından çeşitlilik göstermesi bu farklılığa neden olmuş olabilir. Nitekim araştırmamızda ticari hibritler, köy popülasyonları ve deneysel hibritlerin yanı sıra kendilenmiş hatlardan oluşan bir materyal seti kullanılmıştır.

\subsection{Tane Ölçüm Sonuçları}

Yapılan varyans analizi sonucunda Tane sayısı değerlerinin referans analiz ölçümlerinde ve görüntü işleme analizlerinde, Genotip ve Genotip x Tozlama yöntemi etkileşimine bağlı olarak değiştiği anlaşılmaktadır (Tablo 3). Yapılan varyans analizi sonucunda Tane çevresi değerlerinin SmartGrain analiz ölçümlerinde ve Fiji görüntü işleme analizlerinde, genotip ve $\mathrm{G} x$ $\mathrm{T}$ interaksiyonundan etkilendiği görülmektedir (Tablo 3).

Tablo 3. Tane Özelliklerine İlişkin Varyans Analiz Sonuçları (Table 3. The Results of Variance Analysis for Kernel Traits)

\begin{tabular}{l|c|c|c|c|c|c|c|c}
\hline $\begin{array}{l}\text { Varyans } \\
\text { Kaynağı }\end{array}$ & SD & $\begin{array}{c}\text { Tane Sayısı } \\
\text { (Referans) }\end{array}$ & $\begin{array}{c}\text { Tane Sayısı } \\
(\mathbf{S G})\end{array}$ & $\begin{array}{c}\text { Tane Sayısı } \\
\text { (Fiji) }\end{array}$ & $\begin{array}{c}\text { Tane } \\
\text { Cevresi } \\
(\mathbf{S G})\end{array}$ & $\begin{array}{c}\text { Tane } \\
\text { Cevresi } \\
\text { (Fiji) }\end{array}$ & $\begin{array}{c}\text { Tane } \\
\text { Uzunluğu } \\
\text { (SG) }\end{array}$ & $\begin{array}{c}\text { Tane } \\
\text { Uzunluğu } \\
\text { (Fiji) }\end{array}$ \\
\hline Tekerür & 2 & 6062 & 6176 & 6188 & 2.28 & 4.72 & 0.27 & 0.32 \\
\hline Genotip $(G)$ & 19 & $70840^{* *}$ & $70209^{* *}$ & $69818^{* *}$ & $111.8^{* *}$ & $104.4^{* *}$ & $13.3^{* *}$ & $14.8^{* *}$ \\
\hline Tozlama $(T)$ & 1 & 15061 & 16136 & 12788 & 0.30 & 3.69 & 0.06 & 0.22 \\
\hline GxT & 19 & $21720^{* *}$ & $21263^{* *}$ & $21094^{* *}$ & $5.16^{* *}$ & $7.18^{* *}$ & $0.88^{* *}$ & $1.60^{* *}$ \\
\hline Hata & 78 & 4880 & 4724 & 4791 & 1.75 & 2.35 & 0.26 & 0.35 \\
\hline
\end{tabular}

Yapılan korelasyon analizleri sonuçlarına göre referans ölçüm yöntemleri, SmartGrain ve Fiji yazılımlarında ölçülen tane sayısı değerleri arasında pozitif yönde ve istatistiki olarak önemli bir korelasyon olduğu belirlenmiştir (Şekil 2). Fakat Tane sayısı degerlerine ölçüm sonuçlarına göre ortalamaların (Referans ölçüm yöntemleri, SmartGrain ve Fiji yazılımlarında) kendileme uygulamasının daha düşük bir ranja sahip olduğu görülmüştür. Kahrıman ve ark. (2015). Misırda farklı tozlama yöntemlerinin tane sayısı üzerine önemli bir etkisi olduğunu ve kendilenen koçanlarda tane sayısının açıkta tozlamadan daha düşük olduğu 
bulunmuştur. Çalışmamızda elde edilen sonuçlar da bu araştırmanın sonuçlarına benzerlik göstermektedir.

Mısırda verim birbirine bağlı olan koçan ve tane karakterlerin bir fonksiyonudur (Makanza ve ark., 2018). Genotiplere göre tane sayısı değişkenlik göstermekle birlikte normal bir misır koçanında 350-400 adet tane oluşmaktadır. Tane sayısının belirlenmesi yüksek işgücü ve emek gerektiren bir işlemdir. Çalışmamızda hem Fiji hem de SmartGrain yazılımları ile açıkta veya kendilenmiş koçanlarda tane sayısının yüksek doğrulukla belirlenebileceği tespit edilmiştir. Makanza ve ark. (2018) tarafindan yürütülen çalışmada 180 koçan üzerinde tane sayımı yapılmış referans veriler ile ölçüm sonuçları arasında doğrusal bir korelasyon ( $\mathrm{r}=0.98 ; \mathrm{p}<0.001)$ olduğu tespit edilmiştir. Çalışmamızda yapılan korelasyon analizleri sonucu referans ölçümlerin hem açıkta $(\mathrm{r}=1)$ hem de kendileme $(\mathrm{r}=1)$ tozlamada doğrusal bir korelasyon olduğu görülmüştür. Bu durum referans tohum sayısı değerleri ile görüntü işleme yöntemlerinden elde edilen sonuçların aynı sıralamaya sahip olduğunu göstermektedir.
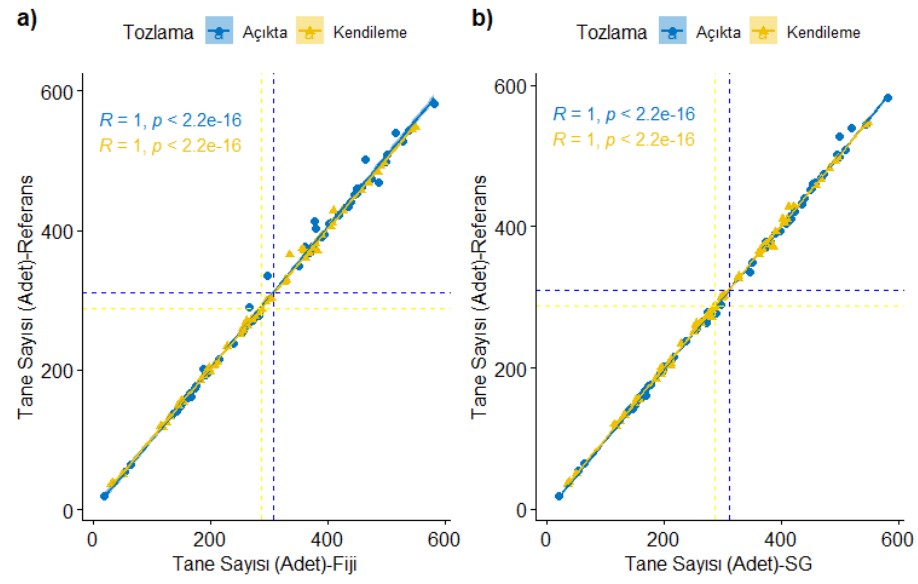

Şekil 2. Açıkta tozlama ve kendileme uygulamalarından referans ve görüntü işleme yöntemleri ile elde edilen tane sayısı ölçümleri arasındaki ilişkiler (Figure 2. Relationships between kernel count measurements obtained by reference and image processing methods from open pollination and selfing teratments)

Bitki gelişimi ve tane dolum döneminde tane boyutu çevre koşullarına göre farklılıklar göstermektedir. Ayrıca tohumun koçan üzerindeki konumu hem tohum büyüklüğünü hemde tohum şeklini belirler. Küçük taneler koçan ucundan, büyük taneler koçanın baş kısmından ve diğerleri ise orta kısımdan çıkma eğilimindedir (Kara, 2011). Düşük verimden kaynaklanan düşük kaliteli tohum, zayıf tohum çimlenme özellikleri ve zayıf fide gücü gibi birçok faktör vardır. Büyük tohumların tane verim performansı küçük tohumların tane verim performansından daha yüksektir (Graven ve Carter, 1990). Korelasyon testi sonuçlarına göre, açıkta tozlama yönteminin $(\mathrm{r}=0.91)$ kendileme yöntemine $(\mathrm{r}=0.89)$ kıyasla nispeten daha güvenilir sonuç verdiği ifade edilebilir.

Korelasyon analizi sonuçlarına göre, SmartGrain analiz ölçümlerinde tane çevresi değerleri ve Fiji görüntü analizleri ile elde edilen değerler arasında pozitif yönde ve istatistiki olarak önemli bir korelasyon olduğu $(r=0.91)$ belirlenmiştir (Şekil 3'a). Farklı tozlama uygulamalarında bu ilişkinin önemli bir değişime uğramadığı dikkat çekmektedir. Tane çevresi ölçümlerinde tespit edilen en düşük ve en yüksek ölçümler dikkate alındığında, tozlama uygulamalarının değişim aralıklarının benzer olduğunu söylemek mümkündür.
SmartGrain analiz ölçümlerinde tane uzunluğu değerleri ve Fiji görüntü analizleri ile elde edilen değerler arasında pozitif yönde ve istatistiki olarak önemli bir korelasyon olduğu (r=0.93) belirlenmiştir (Şekil 3'b). Farklı tozlama uygulamalarında bu ilişkinin önemli bir değişime uğramadığı dikkat çekmektedir. Tane boyundaki değişim aralıkları her iki tozlama yönteminde de birbirine yakın bulunmuştur.
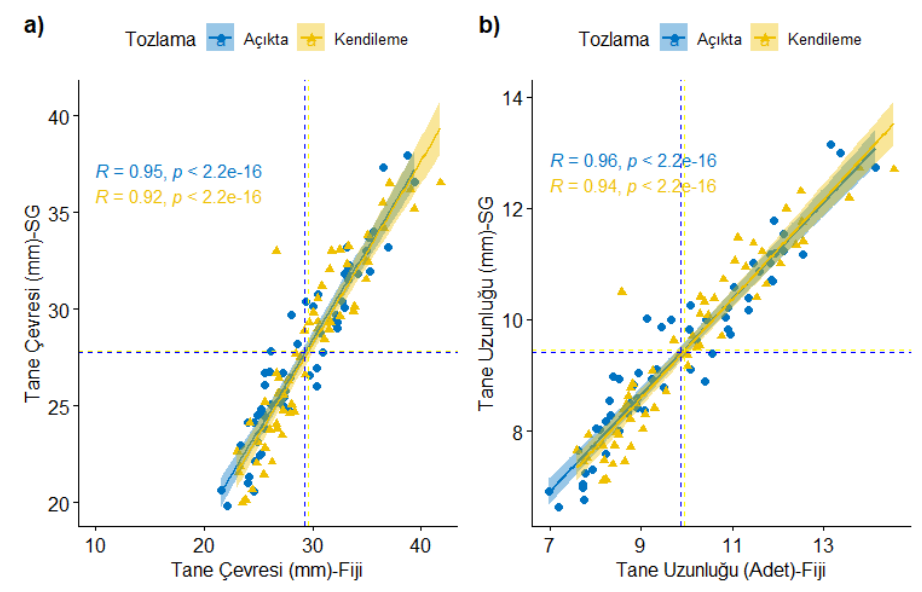

Şekil 3. Açıkta tozlama ve kendileme uygulamalarından SmartGrain ve Fiji analizleri ile elde edilen tane çevresi (a) ve tane uzunluğu (b) ölçümleri arasındaki ilişkiler (Figure 3. Relationships between kernel circumference (a) and kernel length (b) measurements obtained by SmartGrain and Fiji analyzes from open pollination and selfing treatments)

\section{Sonuç}

$\mathrm{Bu}$ araştırma sonucunda mısırda koçan ve tane ölçümlerinde kullanılan yazılımların ölçüm yapılan özelliğe göre değişken sonuç verdiği belirlenmiştir. Çalışmada kullanılan Fiji ve SmartGrain yazılımlarından elde edilen sonuçlardan koçan uzunluğu, koçan çapı, tane uzunluğu ve tane sayısı değerlerinde yüksek bir korelasyon olduğu belirlenmiştir. Özellikle koçanda tane sayısını belirlemede her iki yazılımında aynı sonuçlar verdiği gözlemlenmiştir. Tane eni ölçümlerinde ise program çıktılarının düşük bir benzerliğe sahip olduğu görülmüştür. Kullanılan tozlama uygulmasının etkileri dikkate alındığında koçan çapı ve tane çevresi ölçümlerinde kendileme uygulması için farklı programlardan elde edilen sonuçlar arasındaki benzerliğin, açıkta tozlamadan nispeten düşük olduğu bulunmuştur. Diğer özelliklerde ise ölçüm sonuçlarının her iki grubunda da korelasyon katsayılarının aynı olduğu belirlenmiştir. $\mathrm{Bu}$ özelliklerde yapılacak ölçümlerin tozlama yönteminden etkilenmediği ifade edilebilir. Diğer özellikler için ise farklı işleme yöntemlerine ihtiyaç olabilir.

İleriki çalışmalarda farklı görüntü işleme yazılımlarının kullanılmasının ve referans ölçümlerin çeşitlendirilmesinin yararlı olabileceği düşünülmektedir.

\section{Teşekkür}

Bu çalışma TÜBITTAK-2209A Üniversite Öğrencileri Araştırma Projeleri Destekleme Programı kapsamında 1919B012000636 nolu proje ile desteklenmiştir. Desteklerinden ötürü TÜBİTAK'a teşekkür ederiz. 


\section{Kaynakça}

Chen, J., Zhang, L., Liu, S., Li, Z., Huang, R., Li, Y., Cheng, H., Li, X., Zhou, B., Wu, S., Chen, W., Wu, J., \& Ding, J. (2016). The genetic basis of natural variation in kernel size and related traits using a four-way cross population in maize. PLoS ONE, 11(4): e0153428.

Graven, L.M., \& Carter, P.R. (1990). Seed size/shape and tillage system effect on corn growth and grain yield. Journal of Production Agriculture, 3, 445-452.

Kahrıman, F., Egesel, C.Ö., Aydın, T., \& Subaşı, S. (2015). The role of artificial pollination and pollen effect on ear development and kernel structure of different maize genotypes. Journal of Pollination Ecology, 15, 6-14.

Kara, B. (2011). Tohum büyüklüğü ve şeklinin mısırın tane verimine ve bazı başak özelliklerine etkisi. Mahsul Araştırmaları,12(3): 680-685.

Li, T., Qu, J., Tian, X., Lao, Y., Wei, N., Wang, Y., Hao, Y., Zhang, X., Xue, J., \& Xu, S. (2020). Identification of ear morphology genes in maize (Zea mays L.) using selective sweeps and association mapping. Front. Genet., 11, 747.

Liang, X., Wang, K., Huang, C., Zhang, X., Yan, J., \& Yang, W., (2016). A high-throughput maize kernel traits scorer based on line-scan imaging. Measurement, 90, 453-460.

Liu, M., Tan, X., Yang, Y., Liu, P., Zhang, X., Zhang, Y., Wang, L., Hu, Y., Ma, L., Li, Z., Zhang, Y., Zou, C., Lin, H., Gao, S., Lee, M., Lubberstedt, T., Pan, G., \& Shen, Y., (2019). Analysis of the genetic architecture of maize kernel size traits by combined linkage and association mapping. Plant Biotechnology Journal, 18, 207-221.

Makanza, R., Zaman-Allah, M., Cairns, J.E., Eyre, J., Burgueño, J., Pacheco, Á., Diepenbrock, C., Magorokosho, C., Tarekegne, A., Olsen, M., \& Prasannai B.M. (2018). Highthroughput method for ear phenotyping and kernel weight estimation in maize using ear digital imaging. Biomedcentral (BMC), 4, 2-13.

Miller, N.D., Haase, N.J., Lee, J., Kaeppler, S.M., Leon, N., Spalding, E.P., 2017. A robust, high-throughput method for computing maize ear, cob, and kernel attributes automatically from images. The Plant Journal, 89:169-178.

R Core Team, (2019). R: A language and environment for statistical computing. $\mathrm{R}$ Foundation for Statistical Computing, Vienna, Austria.

Severini, A.D., Borras, L., \& Cirilo, A.G. (2011). Counting maize kernels through digital 1mage analysis. Crop Science, 51, 2796-2800.

Tanabata, T., Shibaya, T., Hori, K., Ebana, K., \& Yano, M. (2012). Smart Grain: high-throughput phenotyping software for measuring seed shape through image analysis. Plant Physiology, 160:1871-1880.

Whan, A.P., Smith, A.B., Cavanagh, C.R., Ral, J.P., Shaw, L.M., Howitt, C.A., \& Bischof, L. (2014). GrainScan: a low cost, fast method for grain size and colour measurements. Plant Methods, 10:23.

Wu, A., Zhu, J., Yang, Y., Liu, X., Wang, X., Wang, L., Zhang, H., \& Chen, J. (2018). Classification of corn kernels grades using image analysis and support vector machine. Advances in Mechanical Engineering, 10(12):1-9.

Yusuf, C.S., Makate, N., \& Jacop, R. (2014). Effect of seed size on germination and early growth of maize. International Journal of Scientific and Research Publications, 4, 1-3. 